\title{
CD55 Gene
}

National Cancer Institute

\section{Source}

National Cancer Institute. CD55 Gene. NCI Thesaurus. Code C95928.

This gene plays a role in the regulation of the complement cascade. 